\title{
Comparison between two cyclooxygenase inhibitors in an experimental dry eye model in albino rabbits
}

\author{
AMANY HASSAN MOHAMED EL-SHAZLY ${ }^{1}$ \\ AMAL AHMAD EL-GOHARY2 \\ LAILA HASSAN MOHAMED EL-SHAZLY ${ }^{3}$ \\ GHADA GHANEM EL-HOSSARY ${ }^{1}$ \\ 1 Ocular Pharmacology Department \\ Research Institute of Ophthalmology \\ Giza, Egypt \\ 2 Ocular Physiology Department, Research \\ Institute of Ophthalmology, Giza, Egypt \\ 3 Ocular and Pathology Deparment \\ Memorial Institute of Ophthalmology \\ Giza, Egypt
}

\begin{abstract}
The purpose of this study was to compare the topical anti-inflammatory effects of the nonselective cyclooxygenase (COX) inhibitor, ketorolac, with the selective COX-2 inhibitor, nimesulide, in an animal model of dry eye in albino rabbits. All animals were examined by the Schirmer test, tear break-up time (TBUT) and fluorescein corneal staining test. Dry eye model showed significant reduction in tear volume, TBUT, corneal staining and histopathological signs of dryness and inflammation. On treating dry eye model with nimesulide $0.1 \%$ eye drops and ketorolac $0.5 \%$ eye drops, there were improvements in Schirmer test values, TBUT and fluorescein corneal staining and histopathologically reduced inflammatory reaction, with signs of healing and regeneration. Both nimesulide and ketorolac ameliorate atropine sulphate induced dry eye in albino rabbits. The use of selective COX-2 inhibitor, nimesulide, is preferred to avoid local and systemic side effects which may occur with the use of the nonselective COX inhibitor, ketorolac.
\end{abstract}

Keywords: dry eye model, rabbit, atropine sulphate, Schirmer test I, nimesulide, ketorolac

Dry eye syndrome, or keratoconjunctivitis sicca (KCS), is one of the most frequent ocular disorders. It may lead to progressive corneal opacification and blindness (1). Secretory, neuronal and mechanical processes that regulate the production and mixing of tear film constituents are functionally integrated (2). The ageing process, hormonal, environmental, iatrogenic, pharmacological and pathogenic factors may disrupt the tear film with subsequent ocular surface inflammation (3). The hyperosmolar tear film stimulates the production of mitogen-activated protein kinase (4). This initiates a cascade of protein phosphorylation involving other kinases and nuclear transcription factors which stimulate the proinflammatory cytokines and chemokines in tear fluid and conjunctival epithelium in KCS (5).

\footnotetext{
* Correspondence, e-mail: Amany.namaky@yahoo.com
} 
Use of artificial tears is palliative, with some transient symptomatic relief. Inflammatory phenomena may exist even in an apparently normal eye, where they remain subclinical (6). Therefore, pharmacological treatment strategies are targeted specifically against predominant inflammatory mediators. Nonsteroidal anti-inflammatory drugs (NSAIDs) are currently used (7). The nonselective NSAID group inhibits both COX-1 and COX-2 enzymes. Although inhibition of COX-2 enzyme is required for inhibition of the production of inflammatory prostaglandins (PGs), inhibition of COX-1 enzyme is not required because it leads to inhibition of the production of physiological PGs involved in the normal regulation of intraocular pressure and blood aqueous barrier (8). Nimesulide is a NSAID that belongs to COX-2 preferential inhibitors. It inhibits inflammatory PGs, platelet activating factor, tumor necrosis factor, proteinase, histamine, bradykinin and cytokine induced hyperalgesia (9). In addition, it antagonizes $\mathrm{H}_{1}$-histamine receptor activation (10). The present investigation is designed to compare the topical nonselective COX inhibitor, ketorolac, with the selective COX-2 inhibitor, nimesulide, in treating an animal model of dry eye in albino rabbits.

\section{EXPERIMENTAL}

In the dry eye model, the ocular surface tissues (cornea, conjunctiva, accessory lacrimal glands, meibomian glands and main lacrimal glands) interconnected by neuronal reflex loops were inhibited by the use of atropine sulphate $1 \%$ eye drops (Orchidia Pharma, Egypt) (11).

\section{Animals}

Eighteen healthy adult male New Zealand albino rabbits, weighing $1.5-2 \mathrm{~kg}$, aged 3-3.5 months, were used. They were individually housed in separate cages under standardized temperature $\left(25-28{ }^{\circ} \mathrm{C}\right)$, humidity $(50-60 \%)$, and light (12 hours light-dark) conditions. They were fed the standard diet and tap water. All care and handling of rabbits adhered to the ARVO statement for the use of animals in ophthalmic and vision research, with approval of the institutional authority for laboratory animal care and approval from the ethical committee. In all animals, treatments were applied topically in both eyes, three times daily starting at 8 a.m. for the duration prescribed for each group.

Nine animals were used in three control groups, each consisting of three animals, with a total of six eyes in each group. Group 1 - only saline eye drops were applied topically for 17 days (negative control). Group 2 - nimesulide (Alkan Pharmaceuticals, Germany) $0.1 \%$ eye drops were instilled topically for seven days; nimesulide, was dissolved in DMSO (Sigma, Germany). Methyl cellulose, in a concentration of $0.3 \%$, was added to prolong the contact with the eye. Group 3 - ketorolac tromethamin $0.5 \%$ eye drops, dissolved in $0.9 \%$ saline (Samulgin, Amoun Pharmaceuticals, Egypt) were applied topically for seven days. Dry eye model was induced in three animal groups. In all three groups, atropine sulphate $1 \%$ eye drops were instilled three times daily for 17 days. Group $4-$ animals received only atropine sulphate $1 \%$ eye drops. Group 5 - in addition to atropine sulphate $1 \%$ eye drops, nimesulide $0.1 \%$ eye drops were applied topically three times daily for seven days starting on day 10 (half an hour after each instillation of atropine 
sulphate). Group 6 - in addition to atropine sulphate 1\% eye drops, ketorolac $0.5 \%$ eye drops were applied topically three times daily for seven days starting on day 10 (half an hour after each instillation of atropine sulphate).

Ophthalmological examination. - Rabbit eyes were examined daily with a naked eye and by direct ophthalmoscope. All the animals were examined on days zero, 3, 7, 10, 14 and 17 of the experiment with the following tests.

Schirmer test. - Schirmer test-1 (without anaesthesia) was done to measure tear secretion in response to both conjunctival stimulation and basal non-reflex secretion. It was performed using Schirmer strips (SEPO, Egypt) which are made of filter paper of 0.5 $\mathrm{mm}$ width and $3.5 \mathrm{~mm}$ length. The strip was inserted over the inferior lid margin towards the lateral canthus for five minutes. Eyes were left to blink normally. The wet area was measured in millimeters (12).

Tear break-up time (TBUT). - Non invasive TBUT was measured with a hand held tearscope-plus (2413-P-2003, Keeler, UK). The lids were blinked manually to distribute the tear film, then the eye was held open and the time taken for distortion of the reflected image of the tearscope grid was recorded. In each measure, the test was performed two times successively and the average was calculated (13).

Fluorescein corneal staining. - One drop of fluorescein sodium $1 \%$ eye drops (CID, Egypt) was instilled in the conjunctival sac. Three minutes later, the eye was examined using a direct ophthalmoscope with cobalt blue light. The numbers of stained corneal quadrants (superior temporal, inferior temporal, superior nasal and inferior nasal) were recorded. The score of this test was graded from 0 to $4(0=$ no staining) (14). The examiner was blind-folded.

Histopathological examination. - Animals were killed at the end of the $17^{\text {th }}$ day with an overdose of intravenous pentobarbital sodium and their eyes were enucleated. Specimens were taken from central corneas, temporal and nasal bulbar parts of conjunctiva. Tissues were fixed in $10 \%$ formalin and processed to obtain paraffin blocks. Sections of $4-\mu \mathrm{m}$ thickness were obtained and stained with haematoxylin and eosin stains. Sections were examined by light microscopy to assess the histopathological changes of dryness and inflammation.

Statistical analysis. - All results are expressed as mean \pm SD. Comparison between groups was performed using ANOVA followed by a post hoc test.

\section{RESULTS AND DISCUSSION}

\section{Ophthalmological examination}

All animals appeared normal on examination by naked eye and with a direct ophthalmoscope. However, it was noticed that nimesulide eye drops prepared in our laboratory were slightly irritant to rabbit eyes, causing transient moderate hyperemia. The rabbits were annoyed and some itching was observed for 5 minutes after eye drop application, followed by spontaneous relief. Ketorolac did not show that effect.

Schirmer test values of control groups 2 and 3 were not significantly different from those of group 1 (negative control) throughout the whole experiment. Table I shows the 
A. H. M. El-Shazly et al.: Comparison between two cyclooxygenase inhibitors in an experimental dry eye model in albino rabbits, Acta Pharm. 58 (2008) 163-173.

Schirmer test values in the negative control group and in groups 4,5 and 6 (dry eye model induction). There was a gradual and significant decrease in tear volume in the untreated dry eye model (group 4), reaching a mean of $4.17 \pm 0.75 \mathrm{~mm}$ on the $17^{\text {th }}$ day of experiment as compared to the negative control group $(18.83 \pm 3.71) \mathrm{mm}$.

In groups 5 and 6 (dry eye model treated with nimesulide and ketorolac, respectively), there was also a gradual decrease in tear volume until day 10 with values of $5.17 \pm$ $1.17 \mathrm{~mm}$ and $6.0 \pm 1.26 \mathrm{~mm}$, respectively. After initial treatment, groups 5 and 6 showed a significant improvement in Schirmer test values on day $17(14.0 \pm 4.2$ and $18.0 \pm 2.61$ $\mathrm{mm}$, respectively) compared to the untreated model of group $4(4.17 \pm 0.75 \mathrm{~mm})$.

Table I. Schirmer test values ${ }^{a}$

\begin{tabular}{ccccc}
\hline Day & Group 1 & Group 4 & Group 5 & Group 6 \\
\hline 0 & $17.2 \pm 4.4$ & $16.3 \pm 4.8$ & $16.3 \pm 4.5$ & $15.7 \pm 1.7$ \\
\hline $\mathrm{p}_{1}$ & & 0.726 & 0.726 & 0.529 \\
$\mathrm{p}_{2}$ & & 1.0 & 0.779 \\
$\mathrm{p}_{3}$ & & & 0.779 \\
\hline 3 & $17.2 \pm 4.1$ & $11.8 \pm 2.5$ & $11.3 \pm 2.4$ & $12.2 \pm 1.9$ \\
\hline $\mathrm{p}_{1}$ & & $0.004^{\mathrm{b}}$ & $0.002^{\mathrm{b}}$ & $0.006^{\mathrm{b}}$ \\
$\mathrm{p}_{2}$ & & & 0.764 & 0.841 \\
$\mathrm{p}_{3}$ & & & & 0.617 \\
\hline 7 & $17.5 \pm 3.4$ & $8.7 \pm 1.0$ & $6.7 \pm 1.5$ & $8.5 \pm 1.5$ \\
\hline $\mathrm{p}_{1}$ & & $0.000^{\mathrm{b}}$ & $0.000^{\mathrm{b}}$ & $0.000^{\mathrm{b}}$ \\
$\mathrm{p}_{2}$ & & & 0.11 & 0.89 \\
$\mathrm{p}_{3}$ & & & & 0.141 \\
\hline 10 & $17.8 \pm 4.5$ & $6.3 \pm 0.8$ & $5.2 \pm 1.2$ & $6.0 \pm 1.3$ \\
\hline $\mathrm{p}_{1}$ & & $0.000^{\mathrm{b}}$ & $0.000^{\mathrm{b}}$ & $0.000^{\mathrm{b}}$ \\
$\mathrm{p}_{2}$ & & & 0.413 & 0.814 \\
$\mathrm{P}_{3}$ & & & & 0.557 \\
\hline 14 & $18.3 \pm 3.5$ & $5.3 \pm 1.0$ & $9.5 \pm 1.1$ & $13.0 \pm 1.9$ \\
\hline $\mathrm{p}_{1}$ & & $0.000^{\mathrm{b}}$ & $0.000^{\mathrm{b}}$ & $0.000^{\mathrm{b}}$ \\
$\mathrm{p}_{2}$ & & & $0.003^{\mathrm{b}}$ & $0.000^{\mathrm{b}}$ \\
$\mathrm{p}_{3}$ & & & & $0.010^{\mathrm{b}}$ \\
\hline 17 & $18.8 \pm 3.7$ & $4.2 \pm 0.7$ & $14.0 \pm 4.2$ & $18.0 \pm 2.6$ \\
\hline $\mathrm{p}_{1}$ & & $0.000^{\mathrm{b}}$ & $0.014^{\mathrm{b}}$ & 0.648 \\
$\mathrm{p}_{2}$ & & & $0.000^{\mathrm{b}}$ & $0.000^{\mathrm{b}}$ \\
$\mathrm{p}_{3}$ & & & & $0.038^{\mathrm{b}}$ \\
\hline & & & &
\end{tabular}

Data are expressed as mean $\pm \mathrm{SD}, n=6$.

$\mathrm{p}_{1}, \mathrm{p}_{2}, \mathrm{p}_{3}$ compared to group $1,4,5$, resp.

a Schirmer test value $(\mathrm{mm})$ of negative control rabbits (group 1), rabbits with dry eye model induced by atropine sulphate $1 \%$ eye drops three times daily for 17 days (group 4) and rabbits with dry eye model treated 3 times daily for 7 days with either nimesulide $0.1 \%$ eye drops (group 5 ) or ketorolac $0.5 \%$ eye drops (group 6) starting from day 10.

b Significant difference. 
A. H. M. El-Shazly et al: Comparison between two cyclooxygenase inhibitors in an experimental dry eye model in albino rabbits, Acta Pharm. 58 (2008) 163-173.

When the results of groups 5 and 6 were compared with those of group 1 (negative control), there were significant differences in the Schirmer test measures on almost all days of testing. Even after initial treatment, the tear volume measures improved but they were still significantly lower than negative controls. The only exception is the result of group 6 on day 17; ketorolac could improve the Schirmer test value not to be significantly different from the negative control.

Comparing the results of groups 5 and 6 together, there was no significant difference between the two groups until day 10 (starting treatment). On days 14 and 17, ketorolac improved the Schirmer test values more efficiently than nimesulide.

Table II. Tear break-up time values ${ }^{a}$

\begin{tabular}{ccccc}
\hline Days & Group 1 & Group 4 & Group 5 & Group 6 \\
\hline 0 & $18.8 \pm 5.2$ & $22.8 \pm 5.5$ & $21.0 \pm 4.8$ & $19.5 \pm 5.9$ \\
\hline $\mathrm{p}_{1}$ & & 0.210 & 0.491 & 0.831 \\
$\mathrm{p}_{2}$ & & 0.559 & 0.293 \\
$\mathrm{p}_{3}$ & & & 0.632 \\
\hline 3 & $18.3 \pm 4.6$ & $12.3 \pm 3.9$ & $10.0 \pm 4.9$ & $7.3 \pm 2.7$ \\
\hline $\mathrm{p}_{1}$ & & $0.020^{\mathrm{b}}$ & $0.002^{\mathrm{b}}$ & $0.000^{\mathrm{b}}$ \\
$\mathrm{p}_{2}$ & & 0.337 & $0.048^{\mathrm{b}}$ \\
$\mathrm{p}_{3}$ & & & 0.275 \\
\hline 7 & $19.0 \pm 4.3$ & $7.5 \pm 3.2$ & $5.5 \pm 3.5$ & $3.7 \pm 0.8$ \\
\hline $\mathrm{p}_{1}$ & & $0.000^{\mathrm{b}}$ & $0.000^{\mathrm{b}}$ & $0.000^{\mathrm{b}}$ \\
$\mathrm{p}_{2}$ & & 0.296 & 0.053 \\
$\mathrm{p}_{3}$ & & & 0.337 \\
\hline 10 & $19.5 \pm 4.2$ & $4.0 \pm 1.6$ & $3.0 \pm 1.6$ & $3.0 \pm 0.9$ \\
\hline $\mathrm{p}_{1}$ & & $0.000^{\mathrm{b}}$ & $0.000^{\mathrm{b}}$ & $0.000^{\mathrm{b}}$ \\
$\mathrm{p}_{2}$ & & & 0.476 & 0.476 \\
$\mathrm{p}_{3}$ & & & & 1.000 \\
\hline 14 & $19.7 \pm 4.2$ & $2.5 \pm 1.4$ & $8.8 \pm 2.7$ & $8.2 \pm 1.8$ \\
\hline $\mathrm{p}_{1}$ & & $0.000^{\mathrm{b}}$ & $0.000^{\mathrm{b}}$ & $0.000^{\mathrm{b}}$ \\
$\mathrm{p}_{2}$ & & & $0.001^{\mathrm{b}}$ & $0.002^{\mathrm{b}}$ \\
$\mathrm{p}_{3}$ & & & & 0.678 \\
\hline 17 & $19.8 \pm 3.9$ & $1.3 \pm 1.2$ & $13.5 \pm 4.5$ & $12.2 \pm 3.8$ \\
\hline $\mathrm{p}_{1}$ & & $0.000^{\mathrm{b}}$ & $0.006^{\mathrm{b}}$ & $0.001^{\mathrm{b}}$ \\
$\mathrm{p}_{2}$ & & & $0.000^{\mathrm{b}}$ & $0.000^{\mathrm{b}}$ \\
$\mathrm{p}_{3}$ & & & & 0.525 \\
\hline & & &
\end{tabular}

Data are expressed as mean $\pm \mathrm{SD}, n=6$.

$\mathrm{p}_{1}, \mathrm{p}_{2}, \mathrm{p}_{3}$, compared to group $1,4,5$.

a Tear break-up time value (in seconds) of negative control rabbits (group 1), rabbits with dry eye model induced by atropine sulphate $1 \%$ eye drops three times daily for 17 days (group 4) and rabbits with dry eye model treated 3 times daily for 7 days with nimesulide $0.1 \%$ eye drops (group 5) or ketorolac $0.5 \%$ eye drops (group 6) starting from day 10.

b Significant difference. 
A. H. M. El-Shazly et al.: Comparison between two cyclooxygenase inhibitors in an experimental dry eye model in albino rabbits, Acta Pharm. 58 (2008) 163-173.

All control groups showed no significant changes in TBUT throughont the experiment. In the untreated dry eye model (group 4), TBUT values (in seconds) examined on days $3,7,10,14$ and 17 were $12.3 \pm 3.9,7.5 \pm 3.2,4.0 \pm 1.6,2.5 \pm 1.4$ and $1.3 \pm 1.2$, respectively. Group 4 showed a significant decrease in TBUT compared to the negative control of group 1 , was $18.8 \pm 5.2$ on day 0 and $19.8 \pm 3.9$ on day 17 (Table II).

On treating the dry eye model with nimesulide (group 5) or ketorolac (group 6), TBUT values improved significantly on day $14(8.8 \pm 2.7$ and $8.8 \pm 1.8$, for groups 5 and 6 , respectively). On day 17 , they reached $13.5 \pm 4.5$ and $12.2 \pm 3.8$ for groups 5 and 6 , res-

Table III. Fluorescein corneal staining scores ${ }^{a}$

\begin{tabular}{|c|c|c|c|c|}
\hline Days & Group 1 & Group 4 & Group 5 & Group 6 \\
\hline 0 & $0.0 \pm 0.0$ & $0.0 \pm 0.0$ & $0.0 \pm 0.0$ & $0.0 \pm 0.0$ \\
\hline $\mathrm{p}_{1}$ & & 1.000 & 1.000 & 1.000 \\
\hline $\mathrm{p}_{2}$ & & & 1.000 & 1.000 \\
\hline $\mathrm{p}_{3}$ & & & & 1.000 \\
\hline 3 & $0.2 \pm 0.4$ & $1.8 \pm 1.0$ & $1.8 \pm 0.4$ & $1.2 \pm 0.4$ \\
\hline $\mathrm{p}_{1}$ & & $0.000^{\mathrm{b}}$ & $0.000^{\mathrm{b}}$ & $0.010^{\mathrm{b}}$ \\
\hline $\mathrm{p}_{2}$ & & & 1.000 & 0.071 \\
\hline $\mathrm{p}_{3}$ & & & & 0.071 \\
\hline 7 & $0.2 \pm 0.4$ & $2.5 \pm 0.6$ & $2.3 \pm 0.5$ & $2.2 \pm 0.7$ \\
\hline $\mathrm{p}_{1}$ & & $0.000^{b}$ & $0.000^{\mathrm{b}}$ & $0.000^{\mathrm{b}}$ \\
\hline $\mathrm{p}_{2}$ & & & 0.618 & 0.323 \\
\hline $\mathrm{p}_{3}$ & & & & 0.618 \\
\hline 10 & $0.3 \pm 0.5$ & $3.3 \pm 0.5$ & $2.5 \pm 0.5$ & $1.5 \pm 0.5$ \\
\hline $\mathrm{p}_{1}$ & & $0.000^{\mathrm{b}}$ & $0.000^{\mathrm{b}}$ & $0.001^{b}$ \\
\hline $\mathrm{p}_{2}$ & & & $0.013^{b}$ & $0.000^{\mathrm{b}}$ \\
\hline $\mathrm{p}_{3}$ & & & & $0.004^{\mathrm{b}}$ \\
\hline 14 & $0.3 \pm 0.5$ & $3.7 \pm 0.5$ & $1.3 \pm 0.5$ & $1.0 \pm 0.0$ \\
\hline $\mathrm{p}_{1}$ & & $0.000^{\mathrm{b}}$ & $0.001^{b}$ & $0.018^{\mathrm{b}}$ \\
\hline $\mathrm{p}_{2}$ & & & $0.000^{\mathrm{b}}$ & $0.000^{\mathrm{b}}$ \\
\hline $\mathrm{p}_{3}$ & & & & 0.211 \\
\hline 17 & $0.3 \pm 0.5$ & $3.8 \pm 0.4$ & $1.0 \pm 0.6$ & $0.7 \pm 0.5$ \\
\hline $\mathrm{p}_{1}$ & & $0.000^{\mathrm{b}}$ & $0.040^{\mathrm{b}}$ & 0.284 \\
\hline $\mathrm{p}_{2}$ & & & $0.000^{\mathrm{b}}$ & $0.000^{\mathrm{b}}$ \\
\hline $\mathrm{p}_{3}$ & & & & 0.284 \\
\hline
\end{tabular}

Data are expressed as mean $\pm \mathrm{SD}, n=6$

$\mathrm{p}_{1}, \mathrm{p}_{2}, \mathrm{p}_{3}$, compared to group $1,4,5$

a Fluorescein corneal staining scores (number of stained corneal quadrants) of negative control rabbits (group 1), rabbits with dry eye model induced by atropine sulphate $1 \%$ eye drops three times daily for 17 days (group 4) and rabbits with dry eye model treated 3 times daily for 7 days with nimesulide $0.1 \%$ eye drops (group 5 ) or ketorolac $0.5 \%$ eye drops (group 6) starting from day 10.

b Significant difference. 
pectively. These values were still significantly lower than the negative controls. In addition, the effects of the two drugs were not significantly different (Table II).

The control groups (1, 2 and 3) showed almost complete absence of corneal fluorescein staining throughout the duration of the experiment. The untreated dry eye model (group 4) showed a significant degree of corneal staining, with a mean of $3.8 \pm 0.2$ on day 17, as compared to the negative control (group 1) that had a mean of $0.3 \pm 0.5$ (Table III).

On days 10, 14 and 17, corneal staining values in group 5 were $2.5 \pm 0.6,1.3 \pm 0.5$ and $1.0 \pm 0.6$, respectively, and group 6 values were $1.5-0.6,1.0-0.0$ and $0.7-0.5$, respectively. Group 5 and 6 values were significantly lower than the untreated model on days 10,14 and 17, but they were still significantly higher than negative controls on the same days. Only ketorolac could improve the fluorescein corneal staining to a level not to be significantly different from negative controls on day 17 (Table III).

Comparing the effects of the two drugs together, there was no significant difference in fluorescein corneal staining between the two except on day 10 (starting treatment) as ketorolac produced a more significant effect than nimesulide (Table III).

\section{Histopathological examinations}

Histopathological examination of specimens taken from all control groups showed normal appearance of the cornea and conjunctiva (Figs. 1a,b). The untreated dry eye model (group 4) revealed marked histopathological changes after 17 days of topical atropine administration. There are frequent areas of corneal epithelial abrasions and defects with of signs of degeneration such as vacuolated basal epithelial cells leading to microcystoid formation with alternate areas of epithelial cell loss and thinning (Figs. 2a,b). In the same group, the conjunctival epithelium shows areas of squamous metaplasia, hyperplasia and keratinization. Inflammatory cells are infiltrating the subepithelium in the form of lymphocytes, plasma cells and some eosinophils. Goblet cell hyperplasia is also noticed with excessive retention of secretion (Fig. 2c).
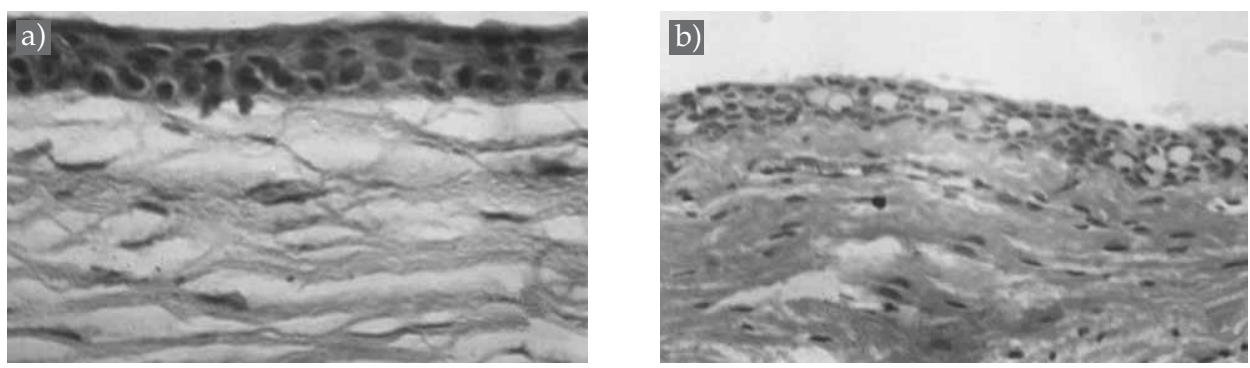

Fig. 1. Light photomicrograph of corneal and conjunctival specimens from control animals showing: a) normal corneal epithelium. Basal cells are columnar with two to three layers of overlying wing cells and flat squamous cells at the apical surface; b) normal bulbar conjunctival epithelium. Epithelial cells are cylindrical to cubical arranged in three to four layers with abundant goblet cells; haematoxilin and eosin X200. 


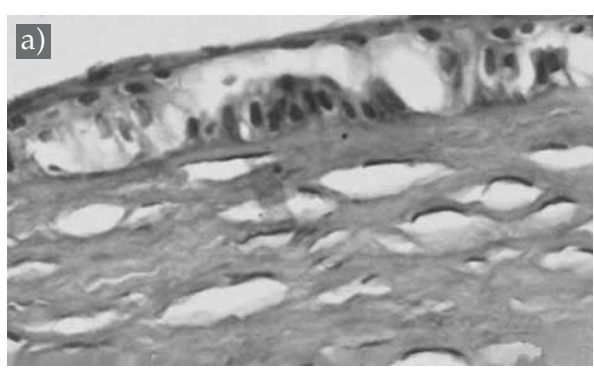

Fig. 2. Light photomicrograph of corneal and conjunctival specimens of untreated dry eye model (group 4) showing: a) cornea with vacuolated basal epithelial cells and microcystoid changes; b) corneal abrasion; c) conjunctiva with subepithelial inflammatory infiltration, advanced intracellular edema with decreased cytoplasmic density, goblet cell hyperplasia, excessive retention of secretion and epithelial hyperplasia; haematoxilin and eo$\sin \mathrm{X} 400$.
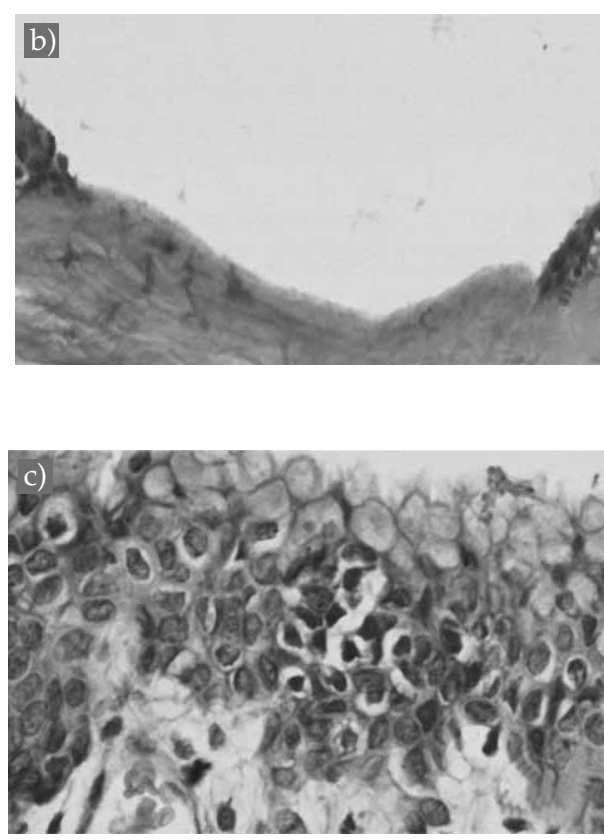

In animals of group 5 (receiving topical nimesulide as treatment for dry eye model), histopathological examination of the cornea showed areas of proliferated epithelium which filled the areas of previous focal defects with the appearance of clusters of clear pinpoint microcysts, indicating healing of areas of previous corneal erosions (Fig. 3a). The conjunctiva showed a reduction of epithelial hyperplasia, a decrease in inflammatory cell reaction and retained secretions in goblet cells (Fig. 3b).

In animals treated with ketorolac (group 6), the specimens reveal signs of healing of corneal erosions in the form of hyperplastic epithelium (Fig. 4a). The conjunctiva showed reduced inflammatory reaction, epithelial hyperplasia and goblet cells hyperplasia, which was more marked in group 6 than in group 5 (Fig. 4b).

The results of the present study are in agreement with those of Sternlicht and Werb (15), who stated that the increased matrix metalloproteinases in the tear fluid in KCS cause lyses of corneal epithelium basement membrane and tight junction proteins. This may lead to increased fluorescein permeability and staining, increased corneal desquamation and punctuate epithelial erosions (15). Also, Dursun and coworkers (16) described a mouse model of KCS with decreased tear volume, altered corneal epithelial barrier function and hyperplasia of conjunctival epithelium. According to Libui et al. (4), dry eye models induced inflammatory reactions that attract and retain inflammatory cells in the conjunctiva (4).

In accord with our work are some reports investigating topical steroids (17), NSAIDS $(2,17,18)$ and cyclosporine A (19) for management of KCS. However, steroids have multiple adverse effects including cataract and increased intraocular pressure (17). 

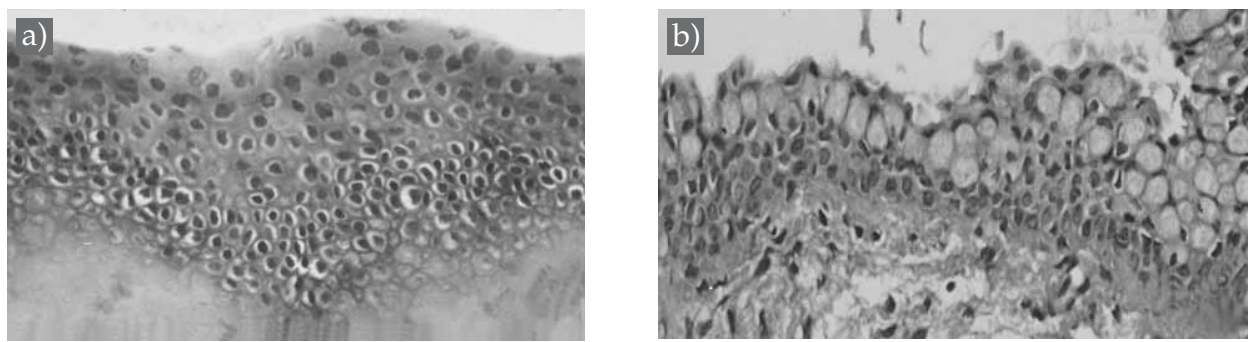

Fig. 3. Light photomicrograph of corneal and conjunctival specimens of dry eye model treated with $0.1 \%$ nimesulide eye drops (group 5) showing: a) cornea with areas of pinpoint microcytic clusters; b) conjunctiva with marked reduction of epithelial hyperplasia, swollen goblet cells with retained secretion and reduction of inflammatory cellular infiltration; haematoxilin and eosin X200.

Moreover, ocular discomforts, including burning, stinging, conjunctival hyperemia and systemic side effects, were reported in patients receiving topical cyclosporine A for 12 months (19). As regards the nonselective COX inhibitors, such as ketorolac, they can gain access to the systemic circulation via nasolacrimal absorption (7), which may cause bronchospasm in asthmatics and postoperative bleeding due to inhibition of platelet aggregation (COX-1 dependent functions) (10).

In the present study, ketorolac produced more improvement compared to nimesulide in the Schirmer test $(18.0 \pm 2.61 \mathrm{~mm}$ and $14.0 \pm 4.2 \mathrm{~mm}$, respectively) as well as fluorescein corneal staining values $(0.67-0.52 \mathrm{~mm}$ and $1.0-0.63 \mathrm{~mm}$, respectively), approaching the controls at the end of experiment (day 17). However, the results of nimesulide were still significantly lower than the controls on day 17 . Yet, the use of the selective COX-2 inhibitor, nimesulide, is preferred to avoid the local and systemic side-effects encountered in prolonged and repeated treatments with the nonselective COX inhibitor, ketorolac.
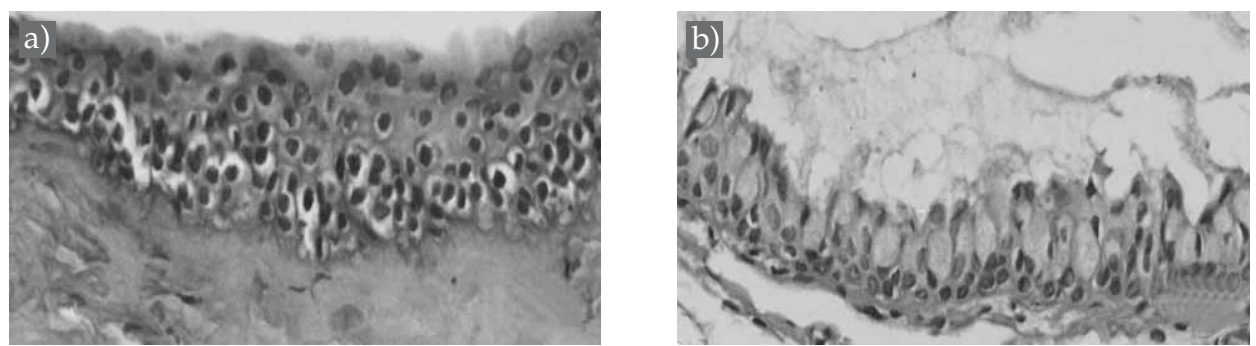

Fig. 4. Light photomicrograph of corneal and conjunctival specimens of dry eye model treated with $0.5 \%$ ketorolac eye drops (group 6) showing: a) cornea with areas of healed previous corneal erosions; b) conjunctiva with decreased inflammatory cellular infiltration and reduction of goblet cell hyperplasia; haematoxilin and eosin X200. 


\section{CONCLUSIONS}

Both nimesulide and ketorolac have beneficial effects in the management of atropine sulphate induced dry eye in albino rabbits. The transient ocular irritant effects produced by nimesulide eye drops, prepared in our laboratory, are better avoided and nonirritant ocular preparations of nimesulide are suggested for further investigation. Further studies are suggested to confirm the safety of nimesulide for prolonged therapy.

\section{REFERENCES}

1. A. Gulati and R. Dana, Keratoconjunctivitis sicca, Clinical aspects, in The Cornea (Eds C. S. Foster, D. T. Azar and C. H. Dohlam), $4^{\text {th }}$ ed., Lippincot, Williams and Wilkins, Philadelphia 2005, pp. 603-626.

2. R. I. Fox and M. Stern, Sjogren's syndrome: Mechanisms of pathogenesis involve interaction of immune and neurosecretory systems, Scand. J. Rheumatol. 31 (2003) 3-13; DOI: 10.1080/ 030097402317474874.

3. S. C. Pflugfelder, Anti-inflammatory therapy of dry eye, Am. J. Ophthalmol. 137 (2004) 337-342; DOI: 10.1016/J.ajo.2003.10.036.

4. L. Libui, D. Li, A. Doshi, W. Farely, R. M. Corrales and S. C. Pflugfelder, Experimental dry eye stimulates the production of inflammatory cytokines and MMP-9 and activates MAPK signaling pathways on the ocular surface, Invest. Ophthamol. Vis. Sci. 45 (2004) 4293-4301; DOI: 10.1167/ iovs.03-1145.

5. A. Solomon, D. Dursun and Z. Liu, Pro and anti-inflammatory forms of interleukins in the tear fluid and conjunctiva of patients with dry eye disease, Invest. Ophthamol. Vis. Sci. 42 (2001) 2283-2292.

6. T. J. Nagelhaut, D. A. Gamache, L. Roberts, M. T. Brady and J. M. Yanni, Preservation of tear fi$\mathrm{lm}$ integrity and inhibition of corneal injury by dexamethasone in a rabbit model of lacrimal gland inflammation-induced dry eye, J. Ocul. Pharmacol. Ther. 21 (2005) 139-148; DOI: 10.1089/ JOP.2005.21.139.

7. L. D. Waterbury, D. Silliman and T. Jalas, Comparison of cyclooxygenase inhibitory activity and ocular anti-inflammatory effects of ketorolac tromethamine and bromfenac sodium, Curr. Med. Res. Opin. 22 (2006) 1133-1140; DOI: 10.1185/03 0079906x112471.

8. J. Damm, T. Rau and A. Pah, Constitutive expression and localization of COX-1 and COX-2 in rabbit iris and ciliary body, Exp. Eye Res. 72 (2001) 611-621; DOI: 10.1006/exer.2001.0977.

9. A. Bertolini, A. Ottani and M. Sandrini, Selective COX-2 inhibitors and dual acting anti-inflammatory drugs, critical remarks, Curr. Med. Chem. 9 (2002) 1033-1034; DOI: 10.2174/0929867024606650 .

10. A. A. Steiner, S. Li, Q. J. Lianos and C. M. Blatteis, Differential inhibition by nimesulide of the early and late phases of intravenous and intracerebral neuroimmunomodulation, 9 (2001) 263-275; DOI: $10.1159 / 000054289$.

11. S. Burgalassi, L. Panichi, P. Chetoni, M. F. Saettone and E. Boldrini, Development of a simple dry eye model in the albino rabbit and evaluation of some tear substituents, Ophthalmic Res. 31 (1999) 229-235; DOI: 10.1159/000055537.

12. X. U. Li, L. Hu, J. Hu and W. Wang, Investigation of dry eye disease and analysis of the pathogenic factors in patients after cataract surgery, Cornea 26 (2007) 516-520; DOI: 10.1097/ico. 0b013e31812f67ca. 
13. L. S. Mengher, A. J. Bron, S. R. Tonge and D. J. Gilbert, Non-invasive instrument for clinical assessment of the precorneal tear film stability, Curr. Eye Res. 4 (1985) 1-7.

14. C. Tamer, I. M. Melek, T. Duman and H. Oksuiz, Tear film tests in Parkinson's disease patients, Ophthalmol. 112 (2005) 1795-1800; DOI: 10.1016/J.ophtha.2005.04.025.

15. M. D. Sternlicht and Z. Werb, How matrix metalloproteinases regulate cell behavior, Annu. Rev. Cell. Dev. Biol. 17 (2001) 463-516; DOI: 10.1146/annurev.Cellbio.17.1.463.

16. D. Dursun, M. Wang, D. Monroy, D. Li, M. E. Stern and S. C. Pflugfelder, A mouse model of KCS, Invest. Ophthamol. Vis. Sci. 43 (2002) 632-638.

17. P. Marsh and S. C. Pflugfelder, Topical nonpreserved methylprednisolone therapy for keratoconjunctivitis sicca in Sjogren's syndrome, Ophthalmology 106 (1999) 811-816; DOI: 10.1016/50161-6420(99)90171-9.

18. R. Schalnus, Topical non steroidal anti-inflammatory therapy in ophthalmology, Ophthalmologica 217 (2003) 89-98; DOI: 10.1159/000068563.

19. S. E. Wilson and H. D. Perry, Long term resolution of chronic dry eye symptoms and signs after topical cyclosporine treatment, Ophthalmology 114 (2007) 76-79; DOI: 10.1016/J.ophtha.2006.05.077.

\section{$S A \check{Z} E T A K$}

\section{Usporedba dvaju inhibitora cikooksigenaze u eksperimentalnom modelu suhog oka u albino kunića}

AMANY HASSAN MOHAMED EL-SHAZLY, AMAL AHMAD EL-GOHARY, LAILA HASSAN MOHAMED EL-SHAZLY i GHADA GHANEM EL-HOSSARY

Cilj istraživanja bila je usporedba topičkog protuupalnog učinka neselektivnog inhibitora ciklooksigenaze (COX), ketorolaka i selektivnog COX-2 inhibitora, nimesulida na animalnom modelu suhog oka u albino kunića. Na životinjama je proveden Schirmerov test, vrijeme prestanka suzenja oka (TBUT) i test bojenja rožnice fluoresceinom. U animalnom modelu suhog oka značajno je smanjen volumen suza, TBUT, bojenje rožnice i histopatološki simptomi suhoće i upale. Obradom suhog oka s kapima za oči koje sadrže $0,1 \%$ nimesulida, odnosno $0,5 \%$ ketorolaka, poboljšane su vrijednosti u Schirmerovom testu, TBUT i bojanje rožnice fluoresceinom, smanjena je upalna reakcija, a na oku su se pokazali simptomi ozdravljenja i regeneracije. I nimesulid i ketorolak smanjuju suhoću oka induciranu atropin sulfatom u albino kunića. Uporaba selektivnog COX-2 inhibitora, nimesulida, se preferira jer se izbjegavaju lokalne i sistemske nuspojave koje se mogu pojaviti uz uporabu neselektivnog COX inhibitora, ketorolaka.

Ključne riječi: model suhog oka, kunić, atropin sulfat, Schirmerov test I, nimesulid, ketorolak

Ocular Pharmacology Department, Research Institute of Ophthalmology, Giza, Egypt

Ocular Physiology Department, Research Institute of Ophthalmology, Giza, Egypt

Ocular and Pathology Department, Memorial Institute of Ophthalmology, Giza, Egypt 